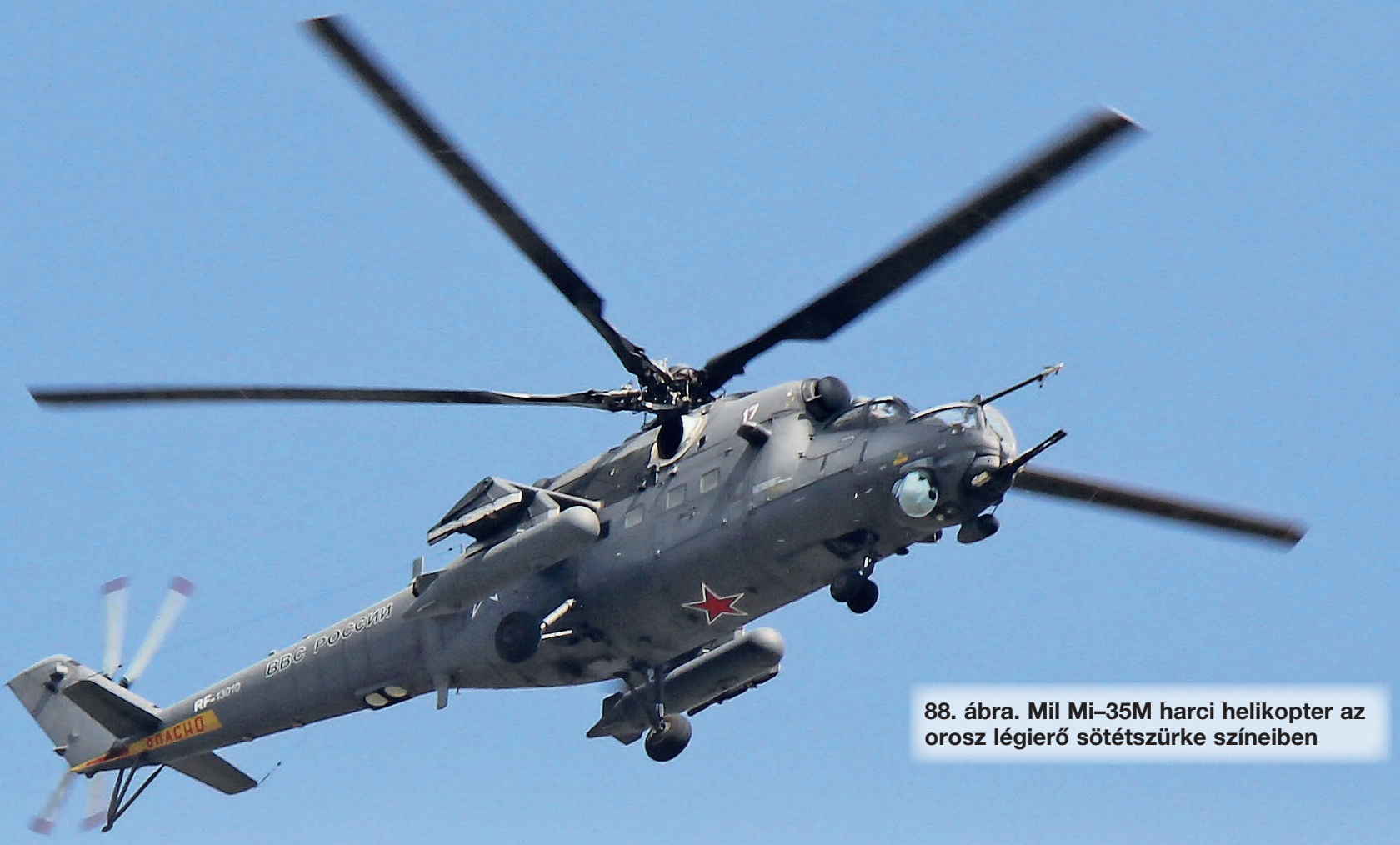

\title{
Zentay Péter*
}

\section{„Vitézek" a Vörös téren - Hadászati csapásmérés ㄸ.resz}

A sorozat előző részében az orosz hadsereg sarkvidéki körülményekre fejlesztett különleges járműveit mutatta be a szerző. A győzelem napi dísszemlékről szóló tudósítás a Jarsz önjáró interkontinentális ballisztikus rakétakomplexum ismertetésével folytatódik, majd a hadrendben lévő helikopterek következnek, amelyek az ünnepi légi parádé résztvevői.

A sarkköri haditechnikai eszközök elhaladása után a győzelem napi díszszemlén következőként az Orosz Hadászati Rakétaerők Kutuzov érdemrenddel kitüntetett 54. rakétagárda ezred hatalmas méretű 15P155M RSz-24 Jarsz (15П155M PC-24 APC) hadászati önjáró interkontinentális ballisztikus rakétakomplexuma mutatkozott be az érdeklődő közönségnek (89., 91. ábra). A rendszer 15U175M (15У175M) autonóm indítóállványain a 15ZS55M (15Ж55M) rakétákat hordozta [205, 206].

$A z$ alakzatot a $30 \mathrm{~mm}$-es gránátvetővel és 7,62 mm-es 6P41 PKP Pecsenyeg géppuskával felszerelt AMN 233114 Tigr-M parancsnoki jármú vezette, valamint oldalról Arbalet-DM távirányított géppuskamodullal felszerelt $4 \mathrm{db}$ 233114 Tigr-M páncélozott jármű és 4 db UAZ-3163 Patriot pick-up kísérte (90. ábra). A Tigr-M páncélozott szállító jármúvekkel már cikksorozatunk első részében találkozhattunk [234]. Az UAZ-3163 Patriot pickup egy könynyű négykerékhajtású terepjáró gépjármü, amellyel az elavultabb UAZ-3151 gépjárművet kívánják leváltani az orosz fegyveres erőknél (az UAZ-3151 a Magyar Honvédségben rendszerben lévő UAZ-469B jármű utódja).
A pickup (jelentése: felkapni, felpakolni) járműváltozatra a szíriai hadműveletek tapasztalatai alapján esett a választás. A jármű kis tömege és fegyverzete, nagy mozgékonyságot és erős tűzerőt biztosít, amelyre nagy szükség mutatkozott az Iszlám Állam terrorszervezet elleni harcok során. A gépjármű fő feladatai: a konvojkíséret, járőrözés, objektumok védelme és útlezárások létesítése. A terepjáró gépjármű katonai változata 96 kW (128 LE) teljesítményű, benzinüzemű motorral, automata sebességváltóval és motor-előmelegítővel rendelkezik [215]. A sivatagi környezetre is előkészített jármű belső terét hőmérsékletszabályozó klímaberendezéssel és nagyobb teljesítményű levegőszűrővel szerelték fel. A jármű 2100 kg és 500 kg tömegű hasznos terhet szállíthat, a személyzet száma maximálisan 9 fő. A jármü fegyverzete a bukókeretre szerelt 12,7 mm-es 6P57 Kord nehézgéppuska és a 7,62 mm-es 6P41 PKP géppuska. A fegyverzet kiegészíthető továbbá $30 \mathrm{~mm}$-es AGSz-17 automata gránátvetővel. A fegyverzet kezelője (egy vagy két fő) a jármű platóján állva kezeli a géppuskákat [216]. A díszszemlén a Tigr és az UAZ járművek konvojszerű kíséretet alkottak az önjáró rakéták körül.

Az RSz-24 Jarsz rakétát az amerikai rakétapajzs [207] áttörésére tervezték, amelynek Európába való telepítése jelenleg is folyamatban van $[208,210]$. Az első sikeres rakétapróbákat már 2007-ben nyilvánosságra hozták, válaszként az addigra már megtervezett amerikai rakétarendszer ellen. Az eszköz a sikeres tesztek után 2010 óta áll

* ORCID: 0000-0002-3161-8829 
rendszerben. A rakétát a Moszkvai Hőtechnikai Intézetben tervezték, Jurij Szolomonov akadémikus vezetésével.

Az új rakétarendszer a Topol-M rakétáktól merőben különbözik, bár külsőre azzal sok hasonlóságot mutat. Amíg a Topol rakétáknak egy robbanófejük van (800 kt - $1 \mathrm{Mt}$ ) addig a Jarsz rakéták többszörös, egymástól függetlenül irányítható robbanófejjel ellátott visszatérő egységekkel rendelkeznek (3-4 db 350-500 kt - a díszszemlén feltehetően ilyenek szerepeltek -, illetve 6-8 db 150 kt töltettel) [209].

A Jarsz rakétarendszert alapvetően arra tervezték, hogy kijátssza a rakétavédelmi rendszereket [212]. A rakéta, repülés közben manővereket hajt végre, továbbá aktív és passzív megtévesztő célcsapdákat is használ. Becslések szerint legalább 60-65\%-os eséllyel képes a rakétavédelmi rendszeren áthatolni [209].

A régebbi Topol-M rakétához képest a találati valószínűsége is javult, jelenleg mintegy $150 \mathrm{~m}$ a találati célköre.

A 15P155M földi telepítésű önjáró rakétarendszer a 15U175M önjáró indítóállványra szerelt 15ZS55M interkontinentális ballisztikus rakétából áll. A 15U175M (15Y175M) önjáró rakétakomplexum fő részei a szálerősített kompozitból készült szállító-indító konténer, a benne lévő 15ZS55M (15\%55M) interkontinentális ballisztikus rakéta és a nyolctengelyes MZKT-79221 (M3KT-79221) hordozó-indító jármű. Egy ezred általában a harcálláspontból, három rakétaosztályból, valamint kiszolgáló, álcázó és védelmet biztosító járművekből áll. Az RSz-24-nek silóból indítható telepített változata is létezik a 15P165M (15П165M) komplexum a 15ZS67 (15\%67) típusjelű rakétákkal. A rendszert úgy tervezték, hogy képes legyen a régi rakéták teljes infrastruktúráját felhasználni. Minden tekintetben kompatibilis a régi silókkal, csak a rakétákat kell a silókba behelyezni.

A háromlépcsős szilárd hajtóanyagú rakéta hatótávolsága meghaladja a $12000 \mathrm{~km}$-t. A rakéták átlagos tömege $49 \mathrm{t}$, amelyből $\sim 1,2$ t a harci rész. A rakéta pályamenti sebessége $20 \mathrm{M}$ feletti. A rakéta autonóm irányítással rendelkezik, pályája fő részén tehetetlenségi ballisztikus pályán halad, amelyet a GLONASS orosz fejlesztésű műholdas helymeghatározó rendszer navigációs jelekkel korrigál. A harci részek, szétválásuk után saját irányítással rendelkeznek [209].

A mobil szállító-indítóállvány a fehérorosz MZKT-79221 alvázra épül, amely önmagában is egy különleges, nagy mozgékonyságú, 16×16-os kerékképletű nehézgépjármü, amelyet korábban a Topol-M rakétákhoz terveztek [211]. Az első három és a hátsó három tengely (összesen 6) egyszerre kormányzott, amely a hatalmas járművet jól manőverezhetővé teszi. Az indítójármű ezzel a módszerrel éri el, hogy forduláskor az összes kerék iránya a mindenkori fordulókör érintőjével essen egybe. Így minden kerék egy adott kör kerületén csúszásmentesen képes haladni, ezzel a fordulókör sugara a lehető legkisebb lesz. A képességet jól szemléltette, hogy a rakétával együtt több mint $24 \mathrm{~m}$ hosszú jármű milyen könnyedén fordult be még a derékszögű Moszkvai kereszteződéseken is (92. ábra). Az összkerékhajtás és a sok kerék kiváló terepjáró és árokáthidaló képességet biztosít a komplexumnak. [213].

Az önjáró interkontinentális ballisztikus rakéták felderítése és megsemmisítése (távolról történő eltalálása) sokkal nehezebb feladat, mint a telepített változatoké, ezért egy országot ért támadásnál az RSz-24 rendszernek sokkal nagyobb a túlélőképessége. Harckészültség esetén a komplexumok elhagyhatják a bázisukat és önállóan tevékenykedhetnek távoli elhagyatott területeken. Az indítójármű 500 km-es hatótávolsága megfelelő ahhoz, hogy a komplexum észrevétlenül tevékenykedhessen egy kisebb ország méretű területen, ahonnan bárhol elvégezheti a ra-

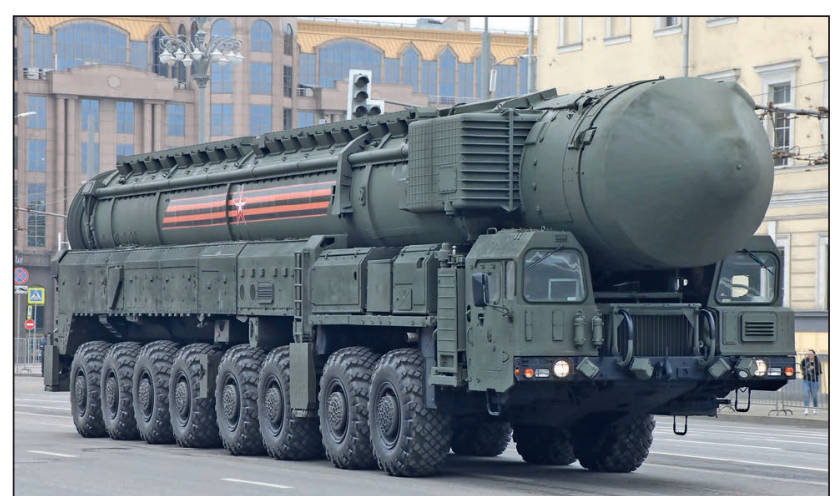

89. ábra. Az 15P155M, RSz-24 Jarsz önjáró interkontinentális ballisztikus rakétakomplexum, jobb oldali nézetben

kéta indítását. Az indítóállvány mindössze 3 fős személyzettel rendelkezik [209].

Menetből átlagosan 7 percet vesz igénybe a rakéta indítása. A rendszer a rakétáját bárhonnan képes indítani, egészen a telephelytől (eltolható garázstetővel), akár egy erdő közepéig. Nagy előny, hogy a rakétaindítást követően a jármü elhagyhatja a helyszínt.

Az indítóállványt számos további jármű kísérheti: kisegítő, logisztikai, híradó, üzemanyag-utánpótlást, harcálláspontot és védelmet biztosító járművek. Éles helyzetben természetesen a rendszer teljesen önállóan is képes a harcfeladat végrehajtására. Az üzemanyag-utánpótlást az indítóállvánnyal megegyező alvázzal ellátott 16×16-os kerékképletű jármű végzi, amelynél a rakéta helyére egy hozzá hasonló méretű és alakú üzemanyagtartály és tárolórész került (93. ábra). Ezt a járművet használják vezetési gyakorlaton is. A komplexum élettartamát - rakétákkal -, átlagosan 20 évre tervezték [209].

A járművet különféle út- és időjárási körülményekre tervezték, a $-50^{\circ} \mathrm{C}$-tól $\mathrm{a}+45^{\circ} \mathrm{C}$-os hőmérséklettartományban. A jármű motorja a 600 kW (800 LE) teljesítményű (21001/min) JaMZ-847.10 (ЯM3-847.10) típusú, négyütemü, vízhűtéses, közvetlen üzemanyag-befecskendezéses turbófeltöltős intercooleres, többfajta üzemanyaggal működő, V12-es henger-elrendezésű dízelmotor. Maximális nyomatéka $3087 \mathrm{Nm}, 1450$ ford/min-nél. A jármű kerékfelfüggesztése független, hidropneumatikus típusú. Az abroncsok (1600×600-685) nyomás-szabályozhatók egy központi egységből, amelynél egyes abroncsok ki is iktathatók. Az abroncsnyomás szabályozását a fülkéből lehet irányítani. $A$ jármű osztott terü. $A$ bal oldali kétüléses, itt helyezkedik el a jármű vezetője is, a jobb oldali egyszemélyes. A túlnyomásos, teljes ABV-védelmet biztosító kabinokat ellátták levegőszűrővel is [211].

90. ábra. Az UAZ-3163 Patriot pickup könnyű személyszállító gépjármúvek bukócsöveire fegyverzetként $12,7 \mathrm{~mm}$-es 6 P57 Kord nehéz géppuskát és a 7,62 mm-es 6P41 PKP géppuskát szereltek fel

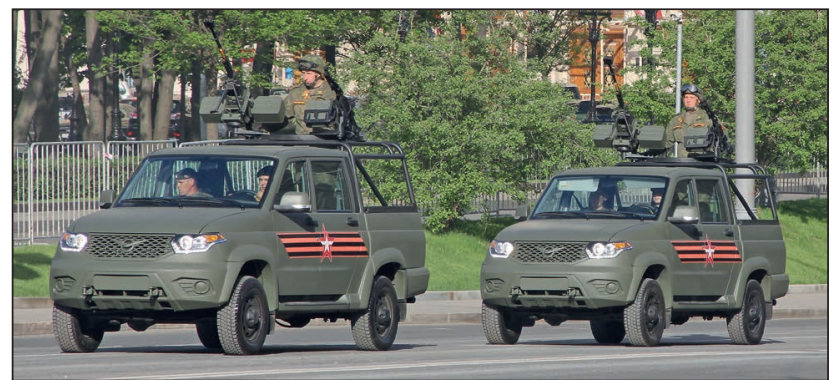




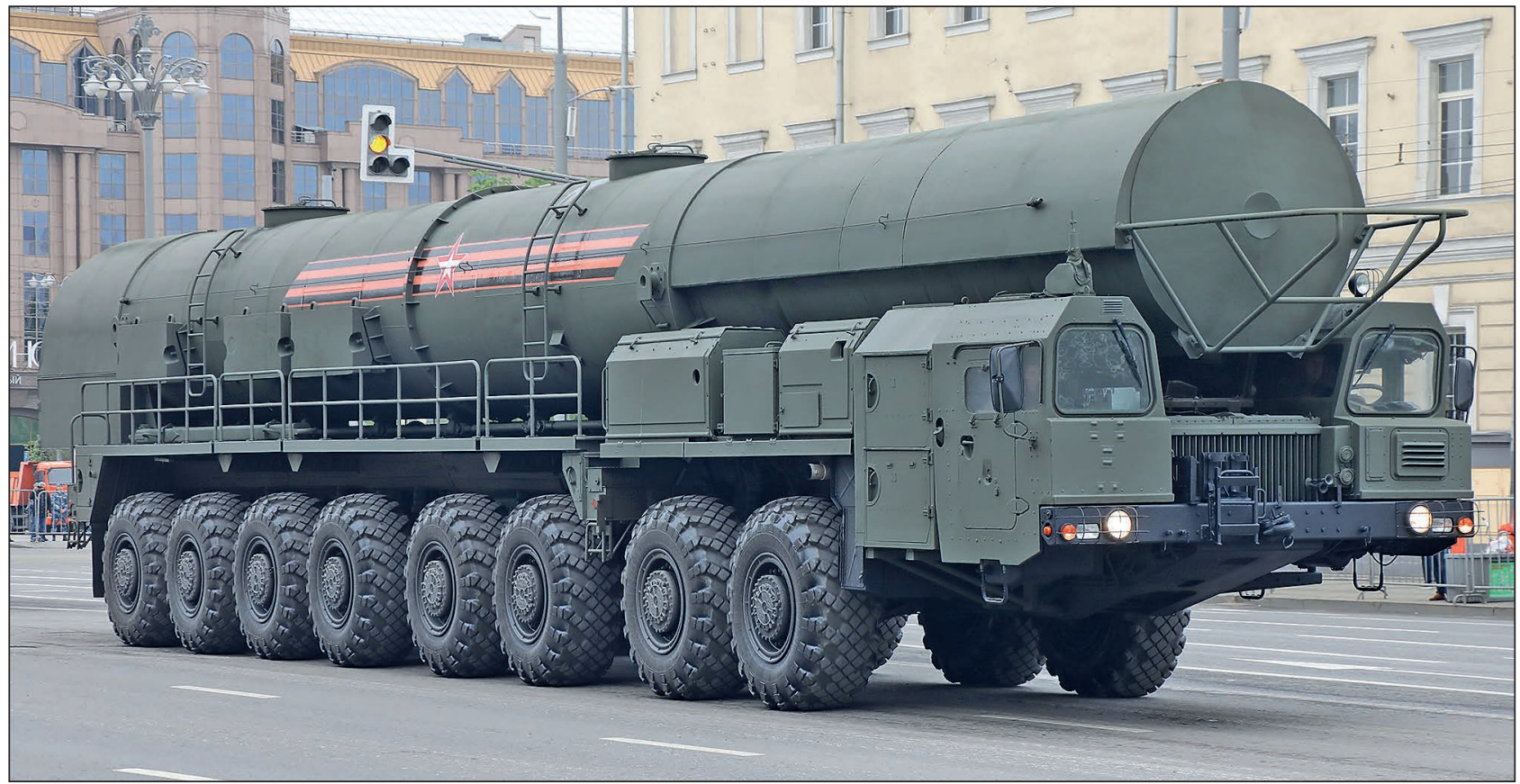

93. ábra. A Jarsz önjáró rakétakomplexum vontató és kisegítő jármúve a Vörös téren nem vonult át, de fontos logisztikai hátteret nyújtott a díszszemle lebonyolításában

szerű moduláris, multifunkciós felépítésű, amely könnyen adaptálható különböző feladatokhoz (94. ábra). Az ergonomikus kialakítással és az eszköz aktív, valamint optoelektronikus zavaró védelmi rendszerével a személyzet biztonságának és kényelmének fokozása volt a tervezők célja. Ezen a téren is nagy fejlődés látható a régebbi BTRhez képest.

A Bumerángok felvonulását követően felcsendült a légierő indulója, amely a légi bemutató kezdetét jelezte.

Az évek során szokatlan események zavarták meg a díszszemlék menetét. 1945-óta az időjárás viszontagságai miatt háromszor kellett törölni (1945, 2017 és 2019-ben [225]) a légi parádét, és 2020-ban, a COVID-19 járvány miatt a légi parádén kívül az összes egyéb felvonulást is.

A légi parádé ${ }^{1}$ összehangolása igen összetett feladat. llyenkor a Kreml Szpasszkaja-bástya harangtornyába települ a díszszemle légi irányítása. A helikopterek és a repülőgépek különböző ${ }^{2}$ légi támaszpontokról indulnak, és Moszkva melletti kijelölt ponton rendeződnek alakzatba. A helikopterek a klini, a vadászgépek a kubinkai, a MiG-

94. ábra. Egy VPK-7829 K-17 Bumeráng kerekes gyalogsági harcjármú közeledik a díszszemlére

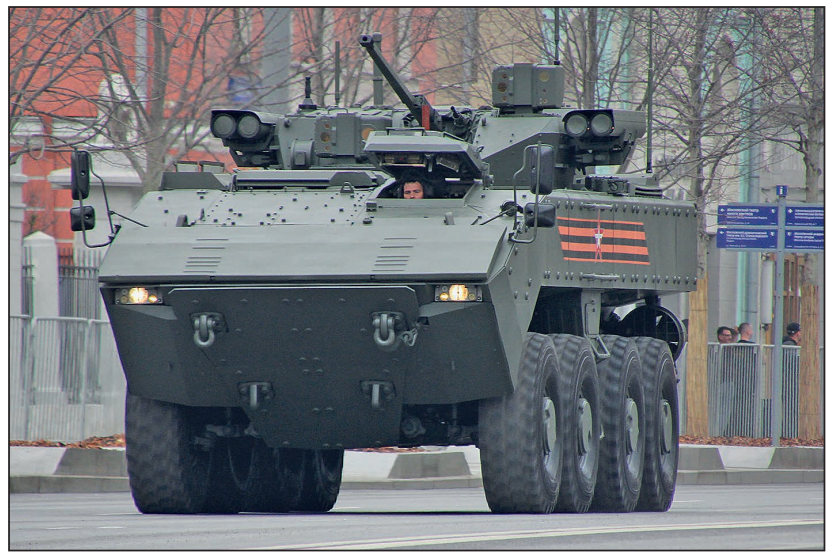

31BM-ek a hotilovoi, a Tu-160M és Tu-95MSz-ek az engelszi, a Tu-22M3-asok a csajkovkai, az AN-124 az uljanovszki, az II-76MD-k a migalovói, a Szu-24M-ek a szavaszlejkai, az A-50 a cskalovszki, az II-78M-ek a djagilevoi támaszpontokról indultak [235]. Több esetben is előfordult, hogy egy alakzatban repülő járművek különböző támaszpontokról érkeztek.

A légi bemutatót a lassabban repülő forgószárnyas szekció kezdi. Az első helikopteralakzat a felvezető Mil Mi-26 és négy Mil Mi-8 AMTS helikopterből állt (99. ábra).

A Mi-26 jelenleg a világ legnagyobb hadrendben álló szállítóhelikoptere (100. ábra). Törzshossza $33,7 \mathrm{~m}$, a 8 forgószárnylapátból álló rendszer átmérője $32 \mathrm{~m}$, legnagyobb felszálló tömege 56 t, legnagyobb sebessége 295 $\mathrm{km} / \mathrm{h}$, hatótávolsága $800 \mathrm{~km}$. Hajtóművei két, egyenként 8500 kW tengelyteljesítményű D-136 típusú helikopter gázturbina. Belső szállító tere $119 \mathrm{~m}^{3}$, függesztve $20 \mathrm{t}$ terhet képes szállítani [226].

A Mi-8 AMTS szállító- és harci helikopter, a hazánkban jelenleg is rendszerben lévő Mi-8/Mi-1733-es közepes többcélú szállítóhelikopter legkorszerűbb változata (101. ábra). Csapat- és rakományszállítás mellett oldalsó függesztményre szerelve, szinte minden orosz harci helikopter által alkalmazott fegyvert képes használni: a 9M114M/F Sturm-V-t, a 9M120 Ataka irányított páncéltörő rakétát, a 9M39 Igla-V levegő-levegő osztályú rakétát, valamint számos további irányított és nem irányított rakétát. A kétfős személyzet mellett további 28 fő szállítására alkalmas. Méretei és fő paraméterei szinte megegyeznek a Mi-17 helikopterével. Hajtómúvei $2 \mathrm{db}$, egyenként 2245 kW tengelyteljesítményű, TV3-117MT helikopter gázturbina. A helikopter páncélvédett, fegyverzete 2 db 23 mm-es 9A 472-01 GS-23 L gépágyú. A Mi-8AMTS-VA helikopter extrém hideg időjárásra tervezett sarkköri változat [227, 228].

A következő formációt a Mil Mi-35M/24VM, (illetve Mi35PM/24VP-M) „Főnix” harci helikopterek alkották (102. ábra). A Mi-35M a hazánkban is rendszerben lévő Mi-24 (D, V, P típusú) harci helikopter egy újabb változata. A Mi-35M-et a Mi-24VP (valamint a Mi-35PM-et a Mi-24VP) változatból 


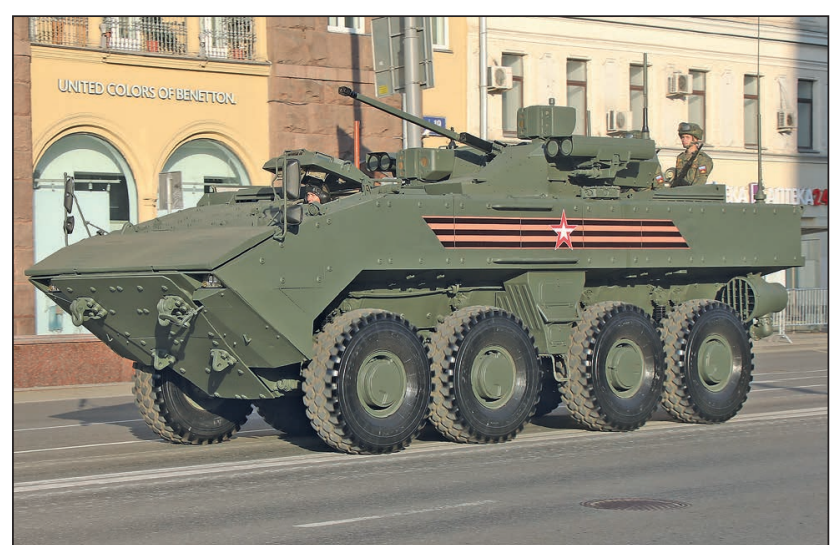

95. ábra. VPK-7829 K-17 Bumeráng kerekes gyalogsági harcjármü. A motor és az áttételi múvek a vezetőtől jobbra találhatók. A képen látszik a gépágyúfegyverzettel párhuzamosított 7,62 mm-es 6P7K PKTM géppuska, és a két célzóberendezés (bal oldali nézet)

hozták létre, elsősorban export célra. Elrendezésében egyedi, mivel nyugati társaitól eltérően a támadó feladata mellett 8 fős deszantot is képes szállítani. A Mi-35M változatnál a futóművek nem behúzhatók (88. ábra). Azonban a futómüvek felfüggesztésébe energiaelnyelő csillapítókat építettek be, amelyekkel zuhanásnál vagy kemény földet érésnél csökkenthető a becsapódás mértéke. Méretei: teljes hosszúsága (forgószárnnyal) 21,6 m, magassága 6,5 m, tömege 12 t, sebessége eléri a $330 \mathrm{~km} / \mathrm{h}$-t. Repülési magassága $4950 \mathrm{~m}$, hatótávolsága 1000/450km. Két, egyenként 1874 kW-os (2510 LE-s) tengelyteljesítményü, TV3-117V helikopter-gázturbina hajtja a forgószárnylapátokat. Fegyverzete a 23 mm-es 9A472 GS-23L ikercsövü gépágyú (NPPU-23) távirányított blokkban (a „P” verziónál jobb oldalon fix elhelyezéssel $30 \mathrm{~mm}$-es 9A623 GS-30-2 ikercsövű gépágyú), továbbá függesztményként $8 \mathrm{db}$ 9K114 Sturm-V vagy 9M120 Ataka-V irányított páncéltörő rakéta, $80 \mathrm{db} 80 \mathrm{~mm}$-es Sz-8 vagy $20 \mathrm{db} 120 \mathrm{~mm}$-es Sz-13 nem irányított rakéta tartozhat [229, 230].

A következőkben négy Mil Mi-28N (éjszakai vadász) (belső borító felső ábra) harci helikopter alkotta formáció

96. ábra. VPK-7829 K-17 Bumeráng kerekes gyalogsági harcjármű hátulról. A képen megfigyelhető a hátsó ajtó, az ajtó feletti kamerás megfigyelörendszer, valamint a kétoldali vízsugár-hajtómú

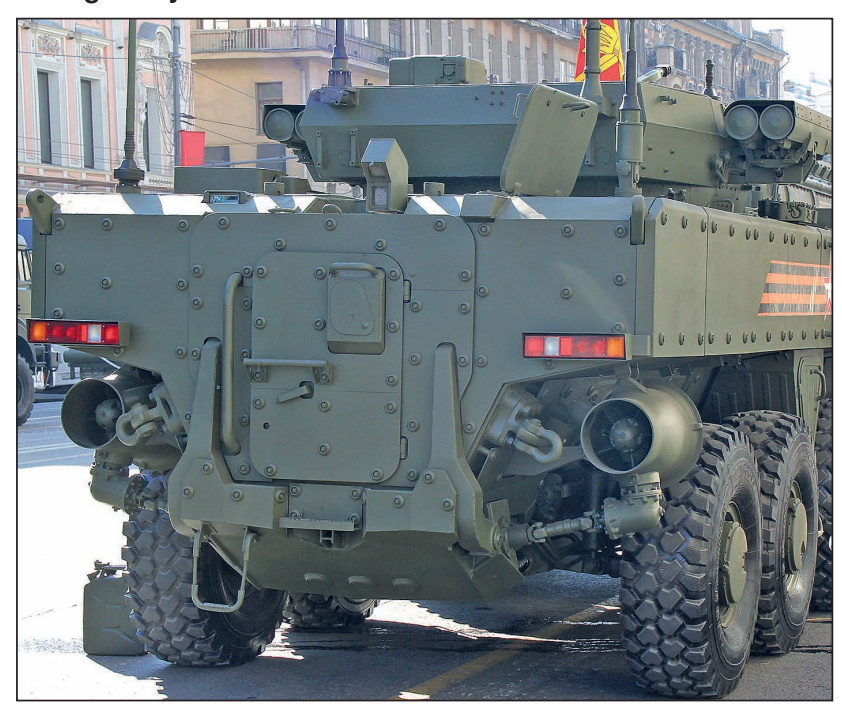

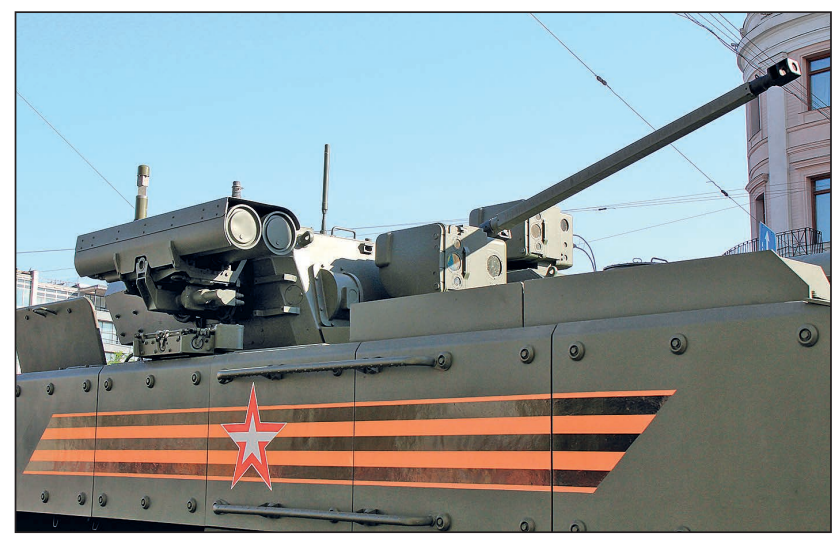

97. ábra. A VPK-7829 K-17 kerekes gyalogsági harcjármú Bumeráng-BM tornya, középen a $30 \mathrm{~mm}$-es $2 A 42$ gépágyúval, oldalán a Kornet-EM páncéltörő rakétákkal

repült el a Vörös tér felett a „Szirti sasok” (Беркутu) légi akrobata csoporttól. A kétszemélyes (a pilóta és a fegyverzet kezelője egymás mögött helyezkedik el) helikopter fő célpontjai a harckocsik, harcjárművek, tüzérségi eszközök, fedetlen élőerő, ellenséges helikopterek és alacsonyan repülő ellenséges objektumok. Hajtóművei: két VK-2500P helikopter-gázturbina, egyenként 1862,5 kW (2508 LE) tengelyteljesítménnyel. A vezetőfülke erősen páncélozott, a kabintető üvege akár 12,7 mm kaliberű lövedék találatának is ellenáll.

A helikoptertörzs hosszúsága $17,05 \mathrm{~m}$, a forgószárny átmérője 17,2 m, magassága 3,82 m, legnagyobb felszálló tömege $12,1 \mathrm{t}$, legnagyobb sebessége $300 \mathrm{~km} / \mathrm{h}$, legnagyobb emelkedési magassága $5600 \mathrm{~m}$. Fegyverzete 30 mm-es 2A42 gépágyú, előre néző NPPU-28 távirányított blokkban, négy külső felfüggesztési pontokon irányított 9K113 Sturm-V 9M114M/F és 9M127-1 Ataka-VM (összesen $16 \mathrm{db}$ ) páncéltörő levegő-föld és 9 M39 Igla-V levegőlevegő rakéták. A nem irányított rakéták közül $80 \mathrm{~mm}$-es Sz-8 levegő-föld (40 db, indítóblokkban) és $130 \mathrm{~mm}$-es Sz-13 levegő-levegő (10 db, indítóblokkban) rakéták elhelyezhetők [231, 232].

A forgószárnyasok zárókötelékét négy Kamov Ka-52 Aligátor kettős koaxiális forgószárny-elrendezésű harci és harcászati felderítő helikopter alkotta (103. ábra).

Fő feladata harckocsik, páncélozott és páncélozatlan járművek, élőerő, ellenséges helikopterek és alacsonyan szálló objektumok megsemmisítése, harci felderítés. Erő-

98. ábra. VPK-7829 K-17 Bumeráng kerekes gyalogsági harcjármú, jobb oldali nézetben

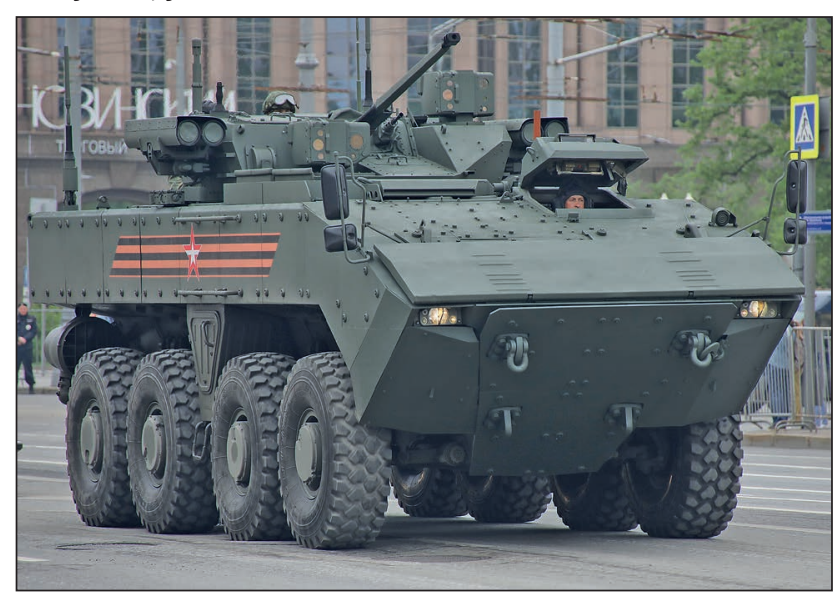




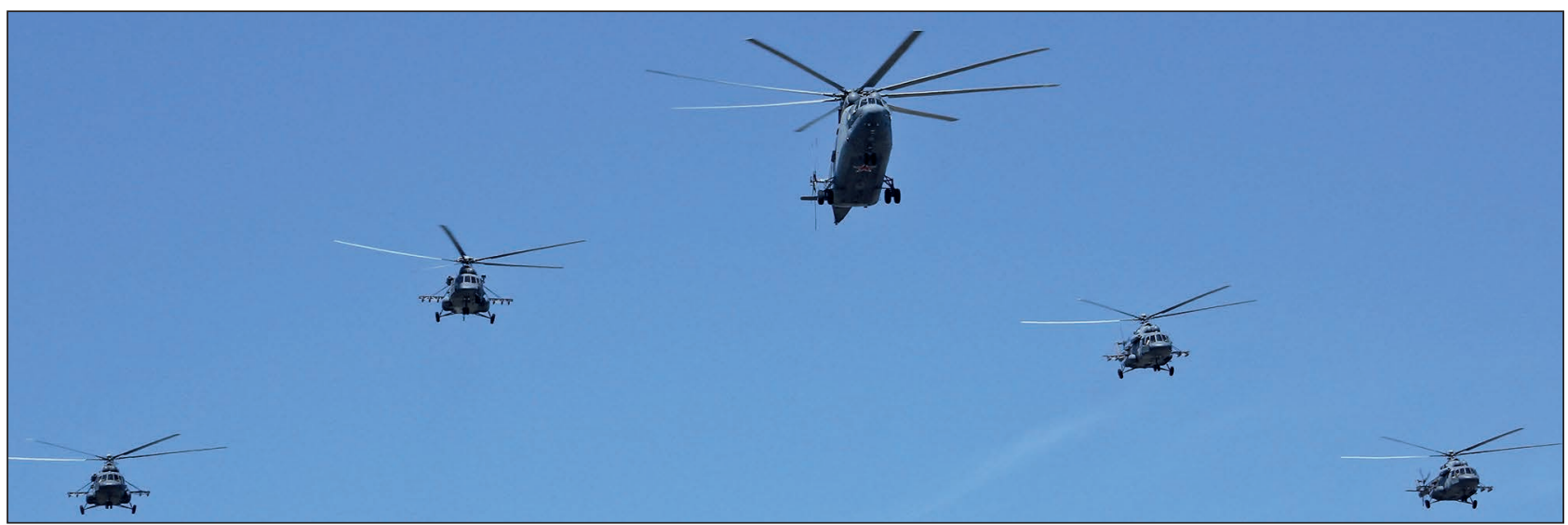

99. ábra. A díszszemle légi parádéját Mi-26-os és négy Mi-8AMTS típusú helikopter kötelékrepülése nyitotta meg

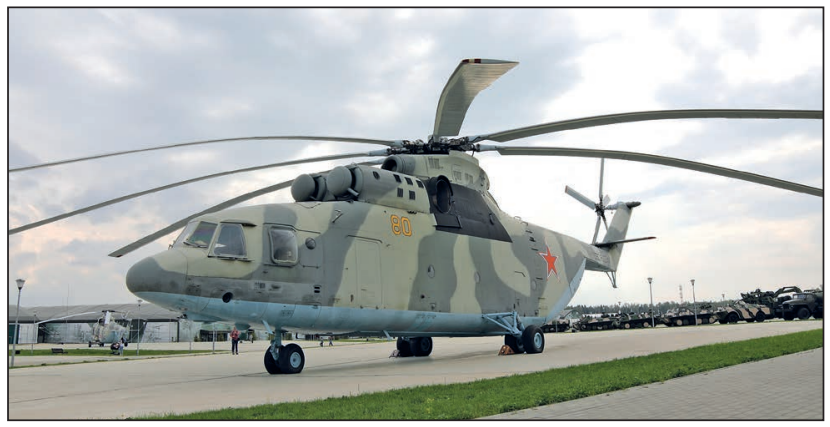

100. ábra. A Mi-26 - a világ legnagyobb hadrendben álló helikoptere

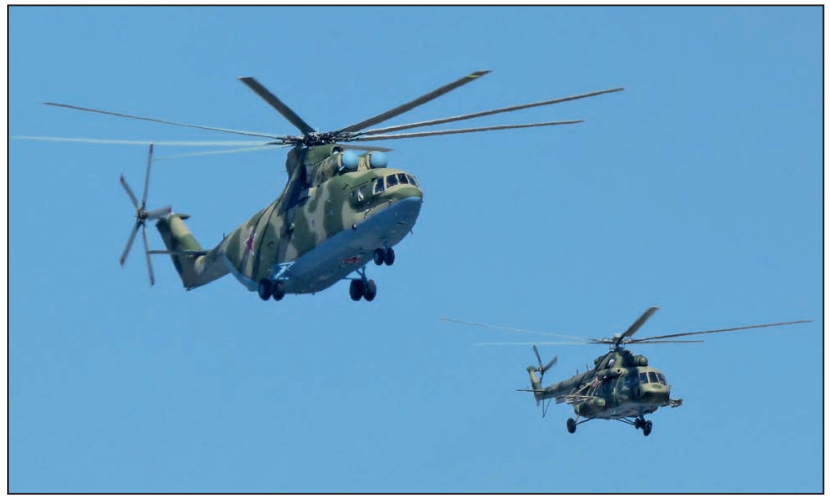

101. ábra. A Mi-8 AMTS többcélú harci szállítóhelikopter külső üzemanyagtartályokkal és az óriási Mi-26 szállítóhelikopter. A kép jól szemlélteti a két helikopter közötti méretkülönbséget

sen páncélozott fülkéjében két kezelő helyezkedik el egymás mellett. A helikopter méretei: a forgószárny átmérője $14,5 \mathrm{~m}$, a törzs hosszúsága $14,2 \mathrm{~m}$, magassága $5 \mathrm{~m}$, legnagyobb felszálló tömege 12,2 t, amelyből 2,8 t fegyverzet, legnagyobb sebessége $300 \mathrm{~km} / \mathrm{h}$. Legnagyobb repülési magassága $5500 \mathrm{~m}$. Függőleges emelkedési sebessége $16 \mathrm{~m} / \mathrm{s}$, hatótávolsága 460/1110 km. Hajtóművei, két VK-2500 helikopter-gázturbina, egyenként 1800 kW tengelyteljesítménnyel. Fegyverzete 30 mm-es 2A42 gépágyú a helikopter jobb oldalán. Hat külső felfüggesztési ponton: irányított (2×6 db 9M120-1 Ataka vagy 9K113U Sturm-VU vagy 9A4172K Vihr-1, akár felváltva is) föld-levegő páncéltörő rakéták, 2×2 db 9M342 Igla-S levegő-levegő irányított rakéta, továbbá nem irányított $(4 \times 20$ db $80 \mathrm{~mm} \mathrm{Sz-8} \mathrm{KOM}$ rakéta $\mathrm{V}-8 \mathrm{~V} 20 \mathrm{~A}$ indítóblokkban és $4 \times 5 \mathrm{db} 122 \mathrm{~mm}$-es

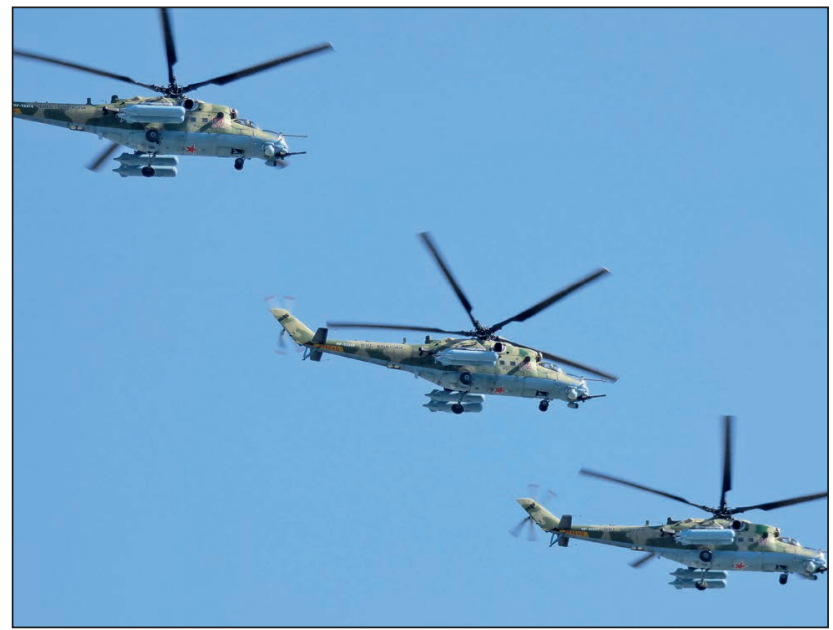

102. ábra. Mi-24VM / Mi-35M harcihelikopter-kötelék, terepszínű festéssel

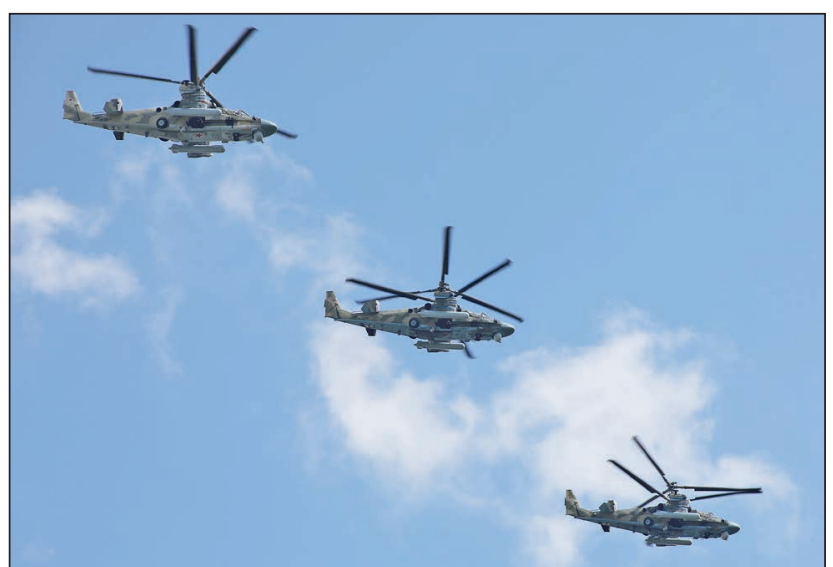

103. ábra. Ka-52 kettős koaxiális forgószárnyú

harcihelikopter-kötelék. A helikopterek két külső üzemanyagtartállyal repülnek

Sz-13 rakéta B-13L5 indítóblokkban) rakéták, illetve $4 \mathrm{db}$ $500 \mathrm{~kg}$-os légi bombák. További érdekessége, hogy a helikopter katapultülésekkel rendelkezik mindkét személyzet számára [232, 233].

A következő részben a légi parádé merevszárnyas eszközeivel foglalkozunk.

(Folytatjuk) 


\section{FELHASZNÁLT IRODALOM}

[205] „Стратегическое ядерное вооружение России, Ракетные войска стратегического назначения" russianforces.com 2018. 02. 21. Elérés: 2020. 07. 02. http://russianforces.org/rus/missiles/;

[206] „Стратегический ракетный комплекс PC-24 „Ярс” (Россия)" Военные люди, 2017. 10. 25. Elérés: 2020. 07. 07. http://voenchel.ru/index.php?newsid=4424;

[207] Browne, Ryan. "U.S. launches long-awaited European missile defense shield" CNN politics, 2016. 05. 12., Elérés: 2020. 07. 02. http://edition.cnn.com/2016/05/11/politics/ nato-missile-defense-romania-poland/index.html;

[208] O’Connor, Tom. "Russian officials say U.S. global missile defense could lead to nuclear war in europe, Newsweek, Tom, 2017. 04. 27., Elérés: 2020. 07. 02. http://www.newsweek.com/russia-us-global-missiledefense-lead-nuclear-war-europe-591244;

[209] "PC-24 Ярс / Тополь-MP - SS-X-29 / SS-29 / SS-27 mod.2 SICKLE-B" Military Russia 2017.09.23. Elérés: 2020. 07. 02. http://militaryrussia.ru/blog/topic-430. html, 2017.12.14.;

[210] Коротченко, Игорь. СНВ, ПРО и будущее российских стратегических ядерных сил http://web. archive.org/web/20100615053302/ (eredetileg: http:// www.oborona.ru/284/112/index.shtml?id=5566);

[211] „МЗКТ-79221 СПЕЦИАЛЬНОЕ КОЛЕСНОЕ ШАССИ MZKT-79221 special wheeled chassis" русская-сила. pdp Elérés: 2020. 07. 02. http://русская-сила.pф/guide/ army/tr/mzkt7922.shtml;

[212] „Russian missile test adds to arms race fears” The Guardian 2007. 05. 30. https://www.theguardian.com/ world/2007/may/30/usa.topstories3;

[213] "Yars, Intercontinental ballistic missile" Military Today 2017. 12. 19. http://www.military-today.com/ missiles/ yars.htm 2017. 12. 19;

[214] Моисеев, Алексей. “В российскую армию вернулись «тачанки», Военные РФ используют в Сирии доработанный пикап "УАЗ», кузов которого превращен в передвижную огневую точку", Известия, 2016.10.14. Elérés: 2020. 07. 02. https://iz.ru/news/637713;

[215] “В войска Центрального военного округа поступают обновленные автомобили УАЗ «Патриот»", Министерство обороны Российской Федерации, https://function.mil.ru/news_page/country/ more.htm?id=12013272@egNews;

[216] "Bumerang: Armored personnel carrier" Military Today 2018.01.07, Elérés: 2020. 07. 02. http://www. military-today.com/apc/bumerang.htm;

[217] "ЭЭоху" установят на "Бумеран" и "Курганец-25", Военно-промышленный курьер" VPK, 2013.12.18, Elérés: 2020. 07. 02. https://vpk.name/ news/102376_epohu_ustanovyat_na_bumerang_i_ kurganec25.html;

[218] „Обнародована информация о перспективном боевом модуле "Эпоха", Военно-промышленный курьер" VPK 2013.08.27, Elérés: 2020. 07. 02. https:// vpk.name/news/95667_obnarodovana_informaciya_ operspektivnom_boevom_module_epoha.html;

[219] „Достойный вклад конструкторов ОАО “Барнаултрансмаш" в укрепление оборонной мощи России, УТД-32ТР" 2010.02.19, 0Elérés: 2020. 07. 02. http://www.barnaultransmash.ru/press.html?44;

[220] “УТД-32ТР" Army Guide 2017.10.14, Elérés: 2020. 07. 02. http://www.army-guide.com/rus/product. php?prodID=5880;
[221] „Бумеранг-бм , ГУП “Конструкторское бюро приборостроения” - КБП” Army Guide 2018.01.12, Elérés: 2020. 07. 02. http://www.army-guide.com/rus/ product5202.html 0;

[222] „БМП К-17 “Бумеранг” ТТХ, Оружие России и мир и военная техника" oruzhie.info 2018.01.12, Elérés: 2020. 07. 02. http://oruzhie.info/bronetekhnika/777bmp-k-17-bumerang;

[223] "Черный Бумер" 8x8: настоящий танк на колесах, Виктор Николаев, КОЛЕСА, 2015.05.17, Elérés: 2020. 07. 02. http://www.kolesa.ru/article/chernyj-bumer-8h8nastojaschij-tank-na-kolesah-2015-05-17;

[224] "Бумеранг": куда пропал лучший в мире БТР?., Военное обозрение, Лев Романов, topwar.ru 2016.01.24, Elérés: 2020. 07. 02. https://topwar. ru/89483-bumerang-kuda-propal-luchshiy-v-mire-btr. html;

[225] „Почему на самом деле отменили воздушную часть Парада Победы. Эксперт рассказал, как принималось решение о запрете полетов над Красной площадью" mk.ru 2017.06.09., Elérés: 2020. 07. 03. http://www.mk.ru/politics/2017/05/09/ pochemu-na-samom-dele-otmenili-vozdushnuyu-chastparada-pobedy.html;

[226] Бобков, Е. „Тяжелый вертолет Ми-26”, Легенды авиации Выпуск 3., Приложение к журналу Стендмастер, 2008;

[227] „Ми-8АМТШ, транспортно-штурмовой вертолет” arms-expo.ru Elérés: 2020. 07. 03. https://www. arms-expo.ru/armament/samples/1001/65179/

[228] Мороз С. Многоцелевой вертолет Ми-8 Авиационный фонд Экспринт, Moszkva, 2005.

[229] Мороз и. Ми-24. Универсальный армейский боевой вертолет Ми-24. Экспринт, Moszkva, 2005;

[230] „Ми-35, многоцелевой ударный вертолет” arms-expo.ru Elérés: 2020. 07. 03. https://www. arms-expo.ru/armament/samples/1000/66495/;

[231] „Ми-28Н Ударный вертолёт” arms-expo.ru Elérés: 2020. 07. 03. https://www.arms-expo.ru/armament/ samples/999/65171/

[232] Якубович Николай. Ударные вертолеты России: Ка-52 “Аллигатор" и Ми-28Н "Ночной охотник”, Война и мы. Авиаколлекция, Яуза, Москва 2016 ISBN 978-5-699-91275-9;

[233] "Ка-52 «Аллигатор», разведывательно-ударный вертолет" arms-expo.ru Elérés: 2020.07.02. https:// www.arms-expo.ru/armament/samples/1000/65842/; [234] „Vitézek” a Vörös téren - Modern csapatszállítás. Korszerű orosz haditechnikai eszközök az elmúlt évek moszkvai győzelem napi díszszemléin I. rész, Zentay Péter, Haditechnika LIII. évf. 3. Sz. (2019) https://doi. org/10.23713/HT.53.3.03;

[235] Несмотря на отмену массовых мероприятий из-за коронавируса, 9 мая 2020 года в Москве состоялся воздушный парад, ЕЛЕНА КОНОВА, афиша москва, 2020.05.15., https://www.kp.ru/afisha/moskva/ daily/aviashou-na-prazdnik/.

\section{JEGYZETEK}

1 A cikkben említett légi járművek részletesebb adataira a forrásjegyzékben hivatkozunk.

$2 \mathrm{Az}$ itt felsorolt légi járműveket a cikksorozat következő részében mutatjuk be.

3 A Mi-17 a Mi-8MT helikopter exportváltozatának típusjele. 